\title{
Canine cavitary effusion: a retrospective study of 304 cases in Brazil
}

\author{
[Efusões cavitárias caninas: estudo retrospectivo de 304 casos no Brasil] \\ F.H. Alonso ${ }^{1}$, C. Bulla ${ }^{2}$, P.R.O. Paes ${ }^{1}$ \\ ${ }^{1}$ Universidade Federal de Minas Gerais - Belo Horizonte, MG \\ ${ }^{2}$ College of Veterinary Medicine - Mississippi State University - Mississippi, USA
}

\begin{abstract}
The objective of this study was to determine the frequency of different categories of specific and general classification in canine cavitary effusions (CE), as well as their association with the underlying etiologies. The laboratorial and clinical data from 304 cases of canine CE were retrospectively assessed. In $32.9 \%$ (100 cases), at least one of the specific classification categories was established, with a subtotal predominance of neoplasia $(42 \%)$, bacterial serositis $(24 \%)$ and hemorrhage $(16 \%)$. Neoplasia was confirmed by effusion cytology in $57.5 \%$ of the cases with histopathological confirmation. From the cases in which the specific classification was not obtained, $35.8 \%$ were classified as modified transudate, $30.4 \%$ as pure transudate, $21.1 \% \%$ as exudate and $12.7 \%$ was not included in any general category. The most common causes of effusion among these cases were hypoproteinemia and/or hipoalbuminemia (HPHA) (25.8\%), hepatopathy (22.5\%), cardiac insufficiency (15.5\%) and cytologically undetected cases of neoplasia (12.4\%). In conclusion, HPHA, hepatopathy and neoplasia represents important etiologies for canine CE development. Classification of effusions, solely based on [TP] and TNCC, might be an inaccurate diagnostic tool of effusions. New laboratorial classification methods for canine CE should be researched.
\end{abstract}

Keywords: body fluid, exudates, peritoneal, pleural and transudates

\section{RESUMO}

O objetivo deste estudo foi determinar a frequência de diferentes categorias de classificação específica e geral em efusões cavitárias (EC) caninas, bem como sua associação com as etiologias subjacentes. Os dados laboratoriais e clínicos de 304 casos de EC canina foram avaliados retrospectivamente. Em 32,9\% (100 casos), pelo menos uma das categorias específicas de classificação foi estabelecida, com predomínio subtotal de neoplasia (42\%), serosite bacteriana (24\%) e hemorragia (16\%). A neoplasia foi confirmada pela citologia da efusão em $57,5 \%$ dos casos com confirmação histopatológica. Dos casos em que a classificação específica não foi obtida (204 casos), 35,8\% foram classificados como transudato modificado, 30,4\% como transudato puro, $21,1 \%$ como exsudato e $12,7 \%$ não foram incluídos em nenhuma categoria geral. As causas mais comuns de efusão nestes casos foram hipoproteinemia elou hipoalbuminemia (HPHA) (25,8\%), hepatopatia (22,5\%), insuficiência cardíaca $(15,5 \%)$ e casos de neoplasia citologicamente não detectados $(12,4 \%)$. Em conclusão, HPHA, hepatopatia e neoplasia representam importantes etiologias para o desenvolvimento da EC canina. A classificação geral de efusões, baseada exclusivamente em proteína e celularidade, pode ser uma ferramenta diagnóstica imprecisa. Novos métodos de classificação laboratorial para ECs caninas devem ser pesquisados.

Palavras-chave: líquido cavitário, exsudato, peritoneal, pleural e transudato

Recebido em 18 de abril de 2018

Aceito em 4 de junho de 2018

E-mail: flaviohalonso@gmail.com 


\section{INTRODUCTION}

Body fluid (BF) is a component that, in physiological situation, is present in the pleural, peritoneal and pericardial cavities, usually in a volume lower than $15 \mathrm{~mL}$ in the peritoneal cavity and $3 \mathrm{~mL}$ in the pleural cavity of dogs (O'Brien e Lumsden, 1988).

When this volume increases, the animal has cavitary effusion (CE), which can be caused by a variety of metabolic, inflammatory, infectious and neoplastic etiologies (Valenciano et al., 2014; Thompson e Rebar, 2016).

In certain cases it is possible to obtain a specific classification of effusion, such as neoplastic, septic, hemorrhagic, chylous, biliary, and uroperitoneal effusions (Bauer, 2014; Valenciano et al., 2014; Thompson e Rebar, 2016). These classifications, obtained mainly through cytological examinations, often require biochemical measurements for their confirmation (Rakich e Latimer, 2011). In cases where the specific classification cannot be established, the general classification can be used as diagnostic guidance to suggest the cause of the effusion, since its categories - pure transudate, modified transudate and exudate - are respectively correlated with different etiologies (Stockham e Scott, 2008; Dempsey e Ewing, 2011; Rakich e Latimer, 2011; Valenciano et al., 2014; Thompson e Rebar, 2016). However, there are different proposals for the interval of protein and cellular concentrations of the three general categories (Stockham e Scott, 2008; Valenciano et al., 2014; Thompson e Rebar, 2016). Additionally, there are rare studies available in the veterinary literature about the correlation of specific and general classification categories with their etiologies, particularly in developing countries (Hirschberger, 1999; Mellanby et al., 2002; Cagle et al., 2014; Bohn, 2017).

The objective of this study was to determine, in canine cavitary effusions, the frequency of different categories of specific and general classification, as well as their association with the underlying etiologies.

\section{MATERIALS AND METHODS}

The experimental design was a retrospective analytical study that involved obtaining laboratorial and clinical data from 304 cases of dogs with CE consulted at the Veterinary Hospital of the Federal University of Minas Gerais (UFMG), Brazil, between 2012 and 2016, under UFMG ethics committee (CEUA/UFMG) number 304/2016. For inclusion in the study, dogs, regardless of breed, gender or age, should have at least one sample of peritoneal, pleural or pericardial fluid submitted for analysis at the Laboratory of Veterinary Clinical Pathology of UFMG. In addition, clinical data such as history, anamnesis and physical examination was collected, and, according to availability, other complementary tests results, such as CBC's, biochemical profiles, imaging, histopathological and surgical/post mortem findings.

BF samples were collected and processed according to the following standard: samples were stored in two tubes, one containing EDTA, and the other with no additives, and analyzed within a maximum period of 12 hours. The sample stored in the presence of EDTA was used for quantitative and qualitative cellular evaluation and the other one for obtaining the physical and biochemical parameters.

The concentrations of total protein ([TP]) and other biochemical components were obtained by Biuret method (Cobas Mira, Hoffmann-La Roche, Switzerland). Red blood cell and total nucleated cell counts (TNCC) were performed with an hemocytometer. The smears, intended for cytological analysis, were made by squash technique and stained with Romanowsky stain (Panótico rápido LB, Laborclin, Brazil).

The general classification system used to categorize the effusions was based on the following intervals: pure transudate: [TP] < $2.0 \mathrm{~g} / \mathrm{dL}$ and TNCC $<1,500 \mathrm{cells} / \mu \mathrm{L} ;$ modified transudate: $[\mathrm{TP}] \geq 2.0 \mathrm{~g} / \mathrm{dL}$ and TNCC < 5,000 cells $/ \mu \mathrm{L}$; and exudate: $\mathrm{PT} \geq 2.0 \mathrm{~g} / \mathrm{dL}$ and TNCC > 5,000cells $/ \mu \mathrm{L}$ (Stockham e Scott, 2008).

The information from additional tests results together with clinical data were used to determine all etiologies, potentially causing CE, to which the animal was submitted by the time BF sample was collected and analyzed. These etiologies were subdivided into 12 categories: hypoproteinemia and/or hipoalbuminemia (HPHA), hepatopathy, neoplasia A, neoplasia B bacterial serositis, heart insufficiency, 
hemorrhage, uroperitoneum, pancreatitis, chylous effusion, biliary effusion and effusions with no defined etiology (idiopathic). The group neoplasia A contained cases in which cytological analysis revealed a neoplastic diagnosis, and the group neoplasia B, cases that were diagnosed via histopathology.

In the group of diagnosed neoplasia (neoplasia A), cases with a neoplastic cell concentration above $20 \%$ were included, with or without histopathological results compatible with neoplastic processes.

For identification of animals affected by hemorrhage, the following criteria were considered in BF samples: supernatant physical aspect, $\mathrm{BF}$ to blood $\mathrm{RBC}$ ratio (both samples from same day), platelet observation and count, neutrophil segmentation and the presence of erythrophagocytosis and hemosiderin.

In the group of hepatopathy, patients with report in their medical records of a definitive diagnosis related to some type of liver disease and those with serum ALT and/or AST enzyme activity greater than three times the upper limit of the reference range were included (Meyer e Harvey, 2004).

In the group of bacterial serositis (septic effusion), were included those cases with cytological record of intracellular bacteria or observation of extracellular bacteria associated with degenerated neutrophils.

In the chylous effusion group, patients should present a cell predominance of small lymphocytes greater than $50 \%$ and $\mathrm{BF}$ triglyceride concentration above $100 \mathrm{mg} / \mathrm{dL}, \mathrm{BF}$ triglyceride to cholesterol ratio greater than 1.0 or $\mathrm{BF}$ to serum triglyceride ratio above 3.0 (Fossum et al., 1986; Waddle e Giger, 1990; Meadows e MacWilliams, 1994).

In the HPHA group, patients with serum [TP] less than $3.12 \mathrm{~g} / \mathrm{dL}$ and/or albumin less than
$1.5 \mathrm{~g} / \mathrm{dL}$, measured within a period of five days before or after BF analysis, were included. The threshold for albumin was based on the information that the majority of mammals presenting protein-poor transudate had a serum albumin concentration lower than $1.5 \mathrm{~g} / \mathrm{dL}$ (Stockham e Scott, 2008). The threshold for [TP] was calculated from the same ratio between the value 1.5 and the lower limit of the reference range for serum albumin, $2.6 \mathrm{~g} / \mathrm{dL}$ (Kaneko et al., 2008). This ratio represents $57.7 \%$ of the lower limit of the reference range, thus generating a value of 3.12 as a threshold for [TP].

In the uroperitoneum group, patients with peritoneal fluid analysis showing a BF to serum creatinine ratio higher than 2.0 were included. For this calculation, the creatinine serum concentration was measured in a sample collected on the same date as the BF (Burrows e Bovee, 1974; Schmiedt et al., 2001) .

The only case of biliary effusion included in this study was diagnosed through the association of cytological analysis with [TP], TNCC and some specific biochemical parameters, such as concentration of bilirubin in the effusion and its relation to the serum concentration. Values higher than 2.0 for this relation with the other compatible parameters indicated this etiology (Owens et al., 2003).

In the pancreatitis and heart insufficiency groups, patients with report in their medical records of definitive diagnosis respectively related to these diseases were included. Cases that could not be associated with any of these or any other etiologies were classified as idiopathic effusions.

\section{RESULTS AND DISCUSSION}

One hundred (32.9\% from 304) cases were included in, at least, one of the specific classification categories. When there were multiple classifications, the most relevant one was considered. The distribution of these cases is presented in Table 1. 
Table 1. Absolute and relative frequencies of the cases of canine effusions classified inside a specific category

\begin{tabular}{lccc}
\hline \multicolumn{1}{r}{ Specific classification } & \# Cases & \% Specific & $\%$ Total \\
\hline Neoplastic effusion & 42 & $42 \%$ & $13.8 \%$ \\
Septic effusion & 24 & $24 \%$ & $7.9 \%$ \\
Hemorrhage & 16 & $16 \%$ & $5.3 \%$ \\
Uroperitoneum & 13 & $13 \%$ & $4.3 \%$ \\
Chylous effusion & 4 & $4 \%$ & $1.3 \%$ \\
Biliary effusion & 1 & $1 \%$ & $0.3 \%$ \\
Subtotal specifics & 100 & $100 \%$ & $32.9 \%$ \\
Subtotal non specifics & 204 & - & $67.1 \%$ \\
Total & 304 & - & $100 \%$ \\
\hline
\end{tabular}

The specific classification of cavitary effusions may be conclusive for a particular etiology, especially when associated with other clinical exams such as history, anamnesis, and physical and imaging tests. The fact that approximately $1 / 3$ of the analyzed cavitary effusions could be inserted in any specific classification category, demonstrates the relevance of the laboratorial analysis to the clinical diagnosis.

In the present study, neoplastic effusion was the most prevalent kind of specific effusion (42\%). These were caused by lymphoma (15), carcinoma of unknown origin (12), mammary gland tumor metastasis (5), primary liver neoplasms (3), malignant intracavitary neoplasia of unknown origin (3), mesothelioma (2), bronchioalveolar carcinoma (1) and sarcoma of unknown origin (1).

However, not every case with neoplastic diagnosis had subsequent histopathological confirmation, and it is possible that some of these cases may be false positives, since one study described a positive predictive value for the diagnosis of neoplastic effusion in dogs through its laboratorial analysis of 95\% (Hirschberger, 1999). The same study reported a sensitivity of $64 \%$ for the cytologic diagnosis of neoplasias in canine cavitary effusions. In the present study, the 42 cases with cytologic diagnosis of neoplasia represented $57.5 \%$ of the 73 cases later confirmed by histopathologic analysis as neoplastic. Neoplasia, therefore, was present in $24.0 \%$ (73/304) of all cases included in the present study. Other retrospective studies involving canine $\mathrm{CE}$ cases revealed frequencies of intracavitary neoplasia varying from 18 to
30\% (Hirschberger, 1999; Mellanby et al., 2002; Bohn, 2017).

The second most found specific category in this study was septic effusion (bacterial serositis), which represented $24 \%$ of the cases (24 out of 100). From the cases in which the cause of septic effusion was identified, all were associated with some type of viscera rupture, with $38.5 \%$ due to traumas, $38.5 \%$ due to gastrointestinal ulcer or obstruction, and $15.4 \%$ as a result of gastrointestinal neoplasia. In the latter cases it was not possible to detect the neoplastic process by means of laboratory analysis. Septic effusions represented 8.7 to $16.0 \%$ of total cases, in similar retrospective studies (Hirschberger, 1999; Mellanby et al., 2002; Bohn, 2017).

Hemorrhagic effusions, the third most common specific cause of cavitary effusions (16\% of specific cases and $5.3 \%$ of total cases) were caused by polytrauma, acute postoperative hemorrhagic syndrome, tumor rupture and pericarditis. Cases of hemorrhagic effusion in which there was cytological identification of neoplasia were grouped with neoplastic cases. Frequencies of hemorrhagic effusions previously reported in other studies were $21 \%$ for peritoneal and pleural cavities and $90 \%$ for pericardial cavity (Hirschberger, 1999; Cagle et al., 2014).

Uroperitoneum diagnosis $(4.3 \%$ of total cases, $13 \%$ of specific cases and $6.1 \%$ of peritoneal cases) were predominantly obtained from suspicion upon laboratorial processing of $\mathrm{BF}$ sample, since these cases usually exhibit a 
typical disproportion between [TP] (values between transudate range) and TNCC (values between exudate range). In rare cases, uroperitoneum occurrence was pointed out as a preliminary clinical suspicion for effusion development. In a survey involving 127 cases of canine peritoneal effusion,

uroperitoneum represented $0.8 \%$ of the total (Hirschberger, 1999) and, in another one, 3.7\% out of 107 analyzed fluids from dogs (Bohn, 2017).

Chylous effusion may be caused by rupture or obstruction of the thoracic duct and lymphangiectasia (Fossum et al., 1986). In the present experiment, from the four cases of chylous effusion (1.3\% of all cases), it was possible to determine, through post mortem investigations, that the primary etiology was mesothelioma in one case. This same case also presented septic effusive component. The other three chylous effusion cases were manifested by unknown causes. Lymphangiectasia was the cause of only one $(0.9 \%)$ canine CE patient in a retrospective study involving the analysis of 107 BF samples from dogs (Bohn, 2017).

The only case of biliary effusion in this study $(0.3 \%$ of total cases) also presented evidence of hepatopathy and hemorrhagic effusive component. The patient was a victim of vehicular collision and during surgery, multiple points of active hemorrhage were found in the liver, duodenum and pancreas. [TP] and TNCC were compatible with exudate, physical aspect was red and turbid, RBC to nucleated cells ratio was 326 , with cell predominance of degenerate neutrophils and observation of intracellular bacteria associated with basophilic amorphous or greenish and golden crystalloid material compatible with free bile. The diagnosis of biliary effusion was confirmed by obtaining the relation between peritoneal and serum bilirubin concentrations (equals 32).

Table 2 presents the distribution of CE cases, in which it was not possible to establish specific classification, according to general classification.
Table 2. Distribution of 204 cases of canine cavitary effusions consulted in the Veterinary Hospital of UFMG, according to the three categories of the general classification.

\begin{tabular}{lcc}
\multicolumn{1}{c}{ General classification } & $\mathrm{n}$ & $\%$ \\
\hline Pure transudate & 62 & 30.4 \\
Modified transudate & 73 & 35.8 \\
Exudate & 43 & 21.1 \\
Unclassified & 26 & 12.7 \\
Total & 204 & 100 \\
\hline
\end{tabular}

When specific classification is not determined, general effusion classification should be an important diagnostic tool for the clinician, if possible to be established. From the $204 \mathrm{CE}$ analysis in which specific classifications could not be obtained (67.1\%), general classification was established in $87.3 \% \quad(n=178)$. In these, categorical distribution was relatively balanced, with a predominance of modified transudates $(35.8 \%)$, followed by pure transudates $(30.4 \%)$ and exudates $(21.1 \%)$. Samples that, due to the discrepancy between [TP] and TNCC, could not be classified in the general classification, corresponded to $12.7 \%$ of cases. It should be noted that other protein concentration and cellularity criteria for determination of general classification, different from those used in this study, are available in the literature and could provide different distributions than those observed in Table 2 (Bohn, 2017).

Out of the 204 cases in which specific CE diagnosis was not obtained, a possible cause for effusion formation could be identified in 129 $(63.2 \%)$ cases. These cases and its respective frequencies in general categories are presented in Table 3.

From the cases that did not result in specific classification, but had at least one etiology identified, hypoproteinemia and/or hypoalbuminemia (HPHA) alone was the most common cause, accounting for $25.8 \%$ of the cases (Table 3). From the 32 cases with this etiology, 30 were included because they had serum albumin concentration lower than $1.5 \mathrm{~g} / \mathrm{dL}$ and two because they had a serum [TP] lower than $3.12 \mathrm{~g} / \mathrm{dL}$. 
Table 2. Cases of canine cavitary effusions, consulted at the Veterinary Hospital of UFMG, that did not result in specific classifications, distributed according to etiology frequency and their respective distributions in general classification categories

\begin{tabular}{|c|c|c|c|c|c|c|}
\hline \multirow{2}{*}{ Etiology } & \multicolumn{2}{|c|}{ Cases } & \multicolumn{4}{|c|}{ General classification } \\
\hline & (n) & $(\%)$ & $\mathrm{PT}(\%)$ & $\operatorname{MT}(\%)$ & Exu. (\%) & Unc. (\%) \\
\hline HPHA alone & 32 & 25.8 & 65.6 & 9.4 & 15.6 & 9.4 \\
\hline Hepatopathy alone & 29 & 22.5 & 31.0 & 34.5 & 24.1 & 10.3 \\
\hline CI alone & 20 & 15.5 & 10.0 & 65.0 & 25.0 & 0 \\
\hline Neoplasia alone & 16 & 12.4 & 0.0 & 38.0 & 42.0 & 20.0 \\
\hline Pancreatitis alone & 1 & 0.8 & 100 & 0 & 0 & 0 \\
\hline HPHA + Hepatopathy & 18 & 14 & 66.7 & 11.1 & 22.2 & 0 \\
\hline HPHA + Neoplasia & 7 & 5.4 & 0 & 12.5 & 50.0 & 37.5 \\
\hline $\mathrm{HPHA}+\mathrm{CI}$ & 2 & 1.6 & 0 & 100 & 0 & 0 \\
\hline HPHA + Pancreatitis & 1 & 0.8 & 0 & 0 & 0 & 100 \\
\hline Pancreatitis + CI & 1 & 0.8 & 0 & 100 & 0 & 0 \\
\hline Hepatopathy + CI & 1 & 0.8 & 0 & 100 & 0 & 0 \\
\hline HPHA + Hepatopathy + Neoplasia & 1 & 0.8 & 0 & 0 & 100 & 0 \\
\hline Total & 129 & 100 & - & - & - & - \\
\hline
\end{tabular}

PT: Pure transudate; MT: Modified transudate; Exu.: Exudate; Unc: Unclassified; HPHA: Hypoproteinemia and/or hypoalbuminemia; CI: Cardiac insufficiency.

Excluding cases of unknown etiology $(n=75)$ out of the 304 cases evaluated, the total number of fluids was $229(75.3 \%)$, with HPHA being the only cause of effusion identified in $14.0 \%$ of these 229 exams. In another study, hypoproteinemia was the cause of $8.2 \%$ of the 183 canine cases of peritoneal or pleural CE (Hirschberger, 1999).

When cases of HPHA alone are added to cases with multiple etiology of the general classification (HPHA + hepatopathy, HPHA + heart insufficiency, HPHA + neoplasia, HPHA + pancreatitis, HPHA + hepatopathy + neoplasia) and to cases of HPHA associated with specific classifications (HPHA + neoplasia and HPHA + bacterial serositis), a total of 77 (33.6\% of 229) cases is obtained in which the hypoproteinemia and/or hypoalbuminemia represented an identified etiology.

Considering that in the 32 cases among the 77 cases of HPHA, no other cause for effusion was determined, it can be concluded that, in cases of CE associated with HPHA, this etiology was responsible for development of, at least, $41.6 \%$ of these effusions.

Regarding the general classification obtained, cases of HPHA alone were predominantly classified as pure transudate $(65.6 \%)$. However, against the expectations, $15.6 \%$ of HPHA alone cases were classified as exudates. This data can support the hypothesis that the present model of effusion general classification may sometimes present flaws in indicating underlying etiology of canine CE cases. In cases in which HPHA was associated with hepatopathy, distribution was similar to that of HPHA alone, with predominance of pure transudates $(66.7 \%)$.

According to Table 3, hepatopathy was also quite representative as an isolated cause of effusions, corresponding to $22.5 \%$ of cases of general classification (29/129) and $12.7 \%$ of cases with established etiology (29/229). In addition to these, hepatopathy was also associated with HPHA, heart insufficiency and neoplasia in another 20 cases of the general classification, adding up to 49 cases or $31.0 \%$ (49/129). In another study, hepatopathy represented only $1.6 \%$ of cases of pleural or peritoneal canine effusion, however the criteria for determining this type of diagnosis were not elucidated (Hirschberger, 1999). Unlike HPHA, CE cases caused by hepatopathy alone were predominantly $(34.5 \%)$ modified transudates.

Cardiac insufficiency (CI) alone accounted for $15.5 \%$ of cases of general classification (20/129) 
and $8.7 \%$ of cases with established etiology (20/229). When added the number of cases of CI alone and the number of cases associated with other etiologies (HPHA + CI, pancreatitis + CI, hepatopathy $+\mathrm{CI}$ ), we obtain a relative frequency to the number of general classification cases of $18.6 \%(24 / 129)$ and of $11.8 \%$ to the number of cases with established etiology (24/229). In a study conducted in Germany, CI represented $35.5 \%$ of 183 cases of canine pleural or peritoneal effusion (Hirschberger, 1999). It is possible that this frequency was considerably higher as a result of a higher average age among the individuals in the study because it was conducted in a country where longevity of companion animals is known to be superior to that of Brazil (Eichelberg e Seine, 1996; Bentubo et al., 2007). Therefore, a higher prevalence for types of disease that affect this age group could be expected.

Regarding general classification, cases of CI alone were associated with effusions classified as modified transudate $(65 \%)$, exudate $(35 \%)$ and simple transudate $(10 \%)$. The four cases of CI in association with other etiologies (HPHA + CI, hepatopathy $+\mathrm{CI}$ and pancreatitis $+\mathrm{CI}$ ) resulted in modified transudate. As discussed previously, CI cases classified as exudates could serve as another indicative evidence that general classification, exclusively based on [TP] and cellularity, is not always the best choice for etiology identification, since it was not found a justification in the literature for exudate formation from CI.

Similar to CI cases, CE caused by neoplasia alone $(n=16)$ also presented a predominance of modified transudates $(38.0 \%)$ and exudates $(42.0 \%)$. However, unlike from the CI group, which presented $10 \%$ of pure transudate cases and any unclassified case, there were no cases classified as pure transudate and $20.0 \%$ did not fit in any general category. This nature of neoplasia alone cases was also observed in those cases in which there was association with the other possible etiologies (HPHA + neoplasia and HPHA + hepatopathy + neoplasia), which resulted in $45.8 \%$ of modified transudates and no case of pure transudate, among all 24 cases of cytologically undiagnosed neoplasia.
Table 4 shows once more the 129 cases that, although not resulting in a specific classification, were associated with a possible cause for $\mathrm{CE}$ formation. Table 4 differs from the previous one because it presents the distribution of observed etiologies within each category of general classification.

According to Table 4, among the cases that did not result in specific classification, pure transudate correlated to HPHA in $73.4 \%$ of the cases. This percentage includes cases of HPHA alone and hepatopathy associated. Adding this number of cases with the number of cases of hepatopathy alone, $93.4 \%$ of pure transudates involved HPHA and/or hepatopathy. CI and pancreatitis were, to a lesser extent, the other causes of pure transudate. In a recent study involving the analysis of 107 canine samples of $\mathrm{CE}$, severe liver disease and protein-losing enteropathy were the most often cause of lowprotein transudates (Bohn, 2017).

Distribution of modified transudate causes is more balanced in comparison to those of pure transudate. In $43.6 \%$ of modified transudate cases, CI was present alone or associated with HPHA, hepatopathy or pancreatitis. Other relevant causes of modified transudate were HPHA (20.5\%) and undiagnosed neoplasm on cytological examination $(18.0 \%)$. In a recent study, modified transudates were most often caused by heart failure and neoplasia in dogs (Bohn, 2017).

Among cases that resulted in exudate, HPHA and/or hepatopathy accounted for almost half (48.5\%) and neoplasia, associated or not with HPHA and/or hepatopathy, more than a third $(36.0 \%)$ of the total. The remaining $15.2 \%$ of the cases of exudate were associated with CI. It should be pointed out that, in table 4, exudate cases from specific classification, such as septic effusion or cytologically identified neoplasia, are excluded. Considering all exudate cases $(n=97)$, the most frequent causes were neoplasia $(34.0 \%)$, HPHA $(25.8 \%)$, hepatopathy $(24.7 \%)$ and bacterial serositis $(21.6 \%)$. In a recent retrospective study, canine exudates were most often caused by septic abdomen $(33.3 \%)$ and neoplasia (27.4\%) (Bohn, 2017). 
Table 3. Cases of canine cavitary effusions, consulted at Veterinary Hospital of UFMG, which did not result in specific classifications, distributed according to the frequency of etiology within each general classification category.

\begin{tabular}{|c|c|c|c|c|c|c|c|c|}
\hline \multirow{3}{*}{ Etiology } & \multicolumn{8}{|c|}{ General Classification } \\
\hline & \multicolumn{2}{|c|}{ Transudate } & \multicolumn{2}{|c|}{$\begin{array}{l}\text { Modified } \\
\text { transudate }\end{array}$} & \multicolumn{2}{|c|}{ Exudate } & \multicolumn{2}{|c|}{ Unclassified } \\
\hline & $\mathrm{n}$ & $\%$ & $\mathrm{n}$ & $\%$ & $\mathrm{n}$ & $\%$ & $\mathrm{n}$ & $\%$ \\
\hline HPHA alone & 21 & 46.7 & 3 & 7.7 & 5 & 15.2 & 3 & 25.0 \\
\hline Hepatopathy alone & 9 & 20.0 & 10 & 25.6 & 7 & 21.2 & 3 & 25.0 \\
\hline CI alone & 2 & 4.4 & 13 & 33.3 & 5 & 15.2 & 0 & 0 \\
\hline Neoplasia alone & 0 & 0 & 6 & 15.4 & 7 & 21.2 & 3 & 25.0 \\
\hline Pancreatitis alone & 1 & 2.2 & 0 & 0 & 0 & 0 & 0 & 0 \\
\hline HPHA + Hepatopathy & 12 & 26.7 & 2 & 5.1 & 4 & 12.1 & 0 & 0 \\
\hline HPHA + Neoplasia & 0 & 0 & 1 & 2.6 & 4 & 12.1 & 2 & 16.7 \\
\hline HPHA + CI & 0 & 0 & 2 & 5.1 & 0 & 0 & 0 & 0 \\
\hline HPHA + Pancreatitis & 0 & 0 & 0 & 0 & 0 & 0 & 1 & 8.3 \\
\hline Pancreatitis + CI & 0 & 0 & 1 & 2.6 & 0 & 0 & 0 & 0 \\
\hline Hepatopathy + CI & 0 & 0 & 1 & 2.6 & 0 & 0 & 0 & 0 \\
\hline $\begin{array}{l}\text { HPHA + Hepatopathy + } \\
\text { Neoplasia }\end{array}$ & 0 & 0 & 0 & 0 & 1 & 3.0 & 0 & 0 \\
\hline Total & 45 & 100 & 39 & 100 & 33 & 100 & 12 & 100 \\
\hline
\end{tabular}

CI: Cardiac Insufficiency; HPHA: Hypoproteinemia and/or hypoalbuminemia.

\section{CONCLUSIONS}

Cytological analysis is a fundamental diagnostic tool for identifying intracavitary neoplasia, and classifying canine CE`s. HPHA, hepatopathy and neoplasia represents important etiologies for canine CE development, with the first two accounting for almost every case of pure transudates, almost half of exudates and more than a third of modified transudates, considering cases with no specific classification. However, the study indicated that general classification system of effusions may be a relatively inaccurate approach to expose the underlying etiology in a considerable portion of canine $\mathrm{CE}$ cases. Hence, the elaboration of new laboratorial classification methods for canine $\mathrm{CE}$, especially those involving biochemistry measurements, are required.

\section{REFERENCES}

BAUER, N. Cytological collection techniques and sample preparation. In: DUNN, J. (Ed.). Manual of diagnostic cytology of the dog and cat. Oxford: Wiley Blackwell, 2014. p.2-15.

BENTUBO, H.D.L.; TOMAZ, M.A.; BONDAN, E.F.; LALLO, M.A. Expectativa de vida e causas de morte em cães na área metropolitana de São Paulo (Brasil). Ciênc. Rural, v.37, p.1021-1026, 2007.
BOHN, A.A. Analysis of canine peritoneal fluid analysis. Vet. Clin. N. Am. Small Anim. Pract., v.47, p.123-133, 2017.

BRUNZEL, N. Pleural, pericardial, and peritoneal fluid analysis. In: BRUNZEL, N. (Ed.). Fundamentals of urine and body fluid analysis. 3.ed. St. Louis: Elsevier, 2013. p.347359.

BURROWS, C.F.; BOVEE, K.C. Metabolic changes due to experimentally induced rupture of the canine urinary bladder. Am. J. Vet. Res., v.35, p.1083-1088, 1974.

CAGLE, L.A.; EPSTEIN, S.E.; OWENS, S.D. et al. Diagnostic yield of cytologic analysis of pericardial effusion in dogs. J. Vet. Intern. Med., v.28, p.66-71, 2014.

DEMPSEY, S.M.; EWING, P.J. A review of the pathophysiology, classification, and analysis of canine and feline cavitary effusions. J. Am. Anim. Hosp. Assoc., v.47, p.1-11, 2011.

EICHELBERG, H.; SEINE, R. Life expectancy and cause of death in dogs. I. The situation in mixed breeds and various dog breeds. Berl. Munch. Tierarztl. Wochenschr., v.109, p.292303, 1996. 
FOSSUM, T.W.; JACOBS, R.M.; BIRCHARD, S.J. Evaluation of cholesterol and triglyceride concentrations in differentiating chylous and nonchylous pleural effusions in dogs and cats. $J$. Am. Vet. Med. Assoc., v.188, p.49-51, 1986.

HIRSCHBERGER, J. Sensitivity and specificity of cytologic evaluation in the diagnosis of neoplasia in body fluids from dogs and cats. Vet. Clin. Pathol., v.28, p.142-146, 1999.

KANEKO, J.; HARVEY, J.; BRUSS, M. Veterinary clinical biochemistry. 6.ed. San Diego: Elsevier, 2008.

MEADOWS, R.L.; MACWILLIAMS, P.S. Chylous effusions revisited. Vet. Clin. Pathol., v.23, p.54-62, 1994.

MELLANBY, R.J.; VILLIERS, E.; HERRTAGE, M.E. Canine pleural and mediastinal effusions: a retrospective study of 81 cases. J. Small Anim. Pract., v.43, p.447-451, 2002.

MEYER, D.; HARVEY, J. Evaluation of fluids: effusions, synovial fluid, and cerebrospinal fluid. In: MEYER, D; HARVEY, J. (Eds.). Veterinary laboratory medicine: interpretation and diagnosis. St. Louis: Saunders, 2004. p.245-250.

O'BRIEN, P.J.; LUMSDEN, J.H. The cytologic examination of body cavity fluids. Semin. Vet. Med. Surg. Small Anim., v.3, p.140-156, 1988.

OWENS, S.D.; GOSSETT, R.; MCELHANEY, M.R.; CHRISTOPHER, M.M.; SHELLY, S.M. Three cases of canine bile peritonitis with mucinous material in abdominal fluid as the prominent cytologic finding. Vet. Clin. Pathol., v.32, p.114-120, 2003.
PORCEL, J M.; LIGHT, R.W. Diagnostic approach to pleural effusion in adults. Am. Family Phys., v.73, p.1211-1220, 2006.

RAKICH, P.; LATIMER, K. Cytology. In: LATIMER, K. (Ed.). Duncan \& Prasse's veterinary laboratory medicine: clinical pathology. 5.ed. Ames: Wiley Blackwell, 2011. p.331-350.

SCHMIEDT, C.; TOBIAS, K.M.; OTTO, C.M. Evaluation of abdominal fluid: peripheral blood creatinine and potassium ratios for diagnosis of uroperitoneum in dogs. J. Vet. Emerg. Crit. Care, v.11, p.275-280, 2001.

STOCKHAM, S.; SCOTT, M. Cavitary effusions. In: STOCKHAM, S; SCOTT, M. (Eds.). Fundamentals of veterinary clinical pathology. 2.ed. Ames: Blackwell, 2008. p.831868.

THOMPSON, C.A.; REBAR, A.H. Body Cavity Fluids. In: RASKIN, R.; MEYE, D. (Eds.). Canine and feline cytology. 3.ed. St. Louis: Elsevier, 2016. p.191-220.

VALENCIANO, A.C.; ARNDT, T.P.; RIZZI, T.E. Effusions: abdominal, thoracic, and pericardial. In: VALENCIANO, A.C.; COWELL, R.L. (Eds.). Cowell and Tyler's diagnostic cytology and hematology of the dogs and cats. 4.ed. St. Louis: Elsevier, 2014. p.244265.

WADDLE, J.R.; GIGER, U. Lipoprotein electrophoresis differentiation of chylous and nonchylous pleural effusions in dogs and cats and its correlation with pleural effusion triglyceride concentration. Vet. Clin. Pathol., v.19, p.80-85, 1990. 